University of New Mexico UNM Digital Repository

2008

\title{
On the Internal Border: Colonial Difference, the Cold War, and the Locations of "Underdevelopment"
}

Alyosha Goldstein

Follow this and additional works at: https://digitalrepository.unm.edu/amst_fsp

\section{Recommended Citation}

Comparative Studies in Society and History 2008;50(1):26-56

This Article is brought to you for free and open access by the American Studies at UNM Digital Repository. It has been accepted for inclusion in American Studies Faculty and Staff Publications by an authorized administrator of UNM Digital Repository. For more information, please contact disc@unm.edu. 


\title{
On the Internal Border: Colonial Difference, the Cold War, and the Locations of "Underdevelopment"
}

\author{
ALYOSHA GOLDSTEIN \\ American Studies, University of New Mexico
}

In 1962, the recently established Peace Corps announced plans for an intensive field training initiative that would acclimate the agency's burgeoning multitude of volunteers to the conditions of poverty in "underdeveloped" countries and immerse them in "foreign" cultures ostensibly similar to where they would be later stationed. This training was designed to be "as realistic as possible, to give volunteers a 'feel' of the situation they will face." With this purpose in mind, the Second Annual Report of the Peace Corps recounted, "Trainees bound for social work in Colombian city slums were given on-the-job training in New York City's Spanish Harlem. ... New Mexican Indian reservations and Spanish-speaking villages make realistic workshops for community development trainees. Puerto Rico provides experience in living in a Latin American environment. The Island of Hawaii, with its multiracial population, remote valleys and varied rural economy, performs a similar function for volunteers headed for Southeast Asia." Local communities throughout the United States were chosen for their apparent similarities to locations abroad such that they might serve as a staging ground for President John F. Kennedy's vaunted Cold War diplomatic venture.

In this essay I argue that U.S. policymaker conceptions of the foreign were constitutive for economic underdevelopment as an emergent category of poverty during the early Cold War. The Peace Corps were one significant example of how the foreign served not simply as a boundary, counterpoint, or disruption to domestic norms, but as integral to the dynamics of liberal

Acknowledgments: Many thanks to Rebecca Schreiber, George Yúdice, Marilyn Young, Alex Lubin, Amanda Cobb, Sam Truett, and Carmen Nocentelli for helpful comments on earlier drafts of this essay, as well as to Andrew Shryock for his enthusiasm and encouragement. I am grateful to archivist Terry Gugliotta for her assistance with the UNM Peace Corps documents. This essay has also benefited tremendously from generous and discerning critique by anonymous reviewers for $\mathrm{CSSH}$.

${ }^{1}$ Peace Corps, Second Annual Report (Washington, D.C: Peace Corps Office of Public Affairs, 1963), 36. 
reform. The discursive link between foreignness and underdevelopment, however, also served political and economic strategies not limited to the prescriptive agendas of reform.

This essay begins with a brief discussion of underdevelopment and its association with the foreign in postwar United States policymaking and social science. In order to demonstrate the rapid appropriation of this logic toward other ends, I then examine a series of legislative proposals by the National Congress of American Indians (NCAI) during the 1950s that explicitly sought to draw on the confluence of U.S. policy constructions of the foreign and underdevelopment. These proposals were modeled on the U.S. Point Four foreign technical assistance program. ${ }^{2}$ However, rather than promoting industrialization and market expansion that U.S. policymakers might readily define as foreign, NCAI proposals aimed to safeguard tribal treaty rights while also securing economic assistance from the U.S. government. The NCAI proposals and lobbying efforts convey both the inadvertent promise of Point Four rhetoric and the decisive barriers to leveraging this rhetoric beyond certain limits.

The essay then turns to Peace Corps community development field training as a means to explore the proliferation of investment in the discursive junction of foreignness and underdevelopment following its official transposition to the margins of the domestic scene. First conceived in 1957 as a "Point Four Youth Corps," the Peace Corps became the preeminent international agency of U.S. liberal reform during its heyday in the 1960s. I juxtapose Peace Corps field training to the NCAI campaign in order to study the ways in which such government initiatives existed in tension with the competing policy objectives, political claims, and economic demands that strategically articulated underdevelopment and foreignness. My examination of Peace Corps field training aims to parse the multiple agents that negotiated for symbolic and material resources through the foreign/underdevelopment rubric. I also focus on the training program in New Mexico, as well as a "pre-training" initiative for American Indians called Project Peace Pipe, in order to consider how state-sanctioned conceptions of underdevelopment, cultural difference, and foreignness ran up against the limit of colonial difference during the 1960s. Colonial difference, as Walter Mignolo uses the term, refers to the disavowal and subalternization of peoples and knowledges - through colonial regimes of racialization, labor exploitation, forced assimilation, and territorial dispossession-upon which Euro-American world power has been historically

\footnotetext{
${ }^{2}$ Initially presented as the fourth policy objective in Truman's 1949 inauguration speech, Point Four was the first extensive U.S. foreign aid program for the non-European world and a corollary to the 1947 Truman Doctrine aimed at recruiting the allegiance of the nonaligned. In 1950, the objectives of Point Four were formalized in the Act for International Development.
} 
predicated. ${ }^{3}$ I use the notion of colonial difference to underscore specifically how this disavowal and subalternization has remained essential to formations of liberal democracy in the United States. I examine the Peace Corps's plans for the training program, the circumstances of its implementation in New Mexico, and the local oppositional uses of the foreign that the program could not accommodate (especially the Alianza Federal de Mercedes). Project Peace Pipe provides an additional vantage point from which to interrogate the permissible variations and forbidden referents of foreignness as a provisional catalyst.

I argue that U.S. policymakers seized upon the foreign/underdevelopment conjunction when it could be cast as a transitional moment in the process of incorporation and assimilation, but when the conjunction threatened to appear as a consequence of market or colonial relations they considered it not only inassimilable but impermissible. Such groups as the Alianza quite deliberately mobilized around the latter, while other New Mexicans, aiming to take advantage of Peace Corps training constructs for their own purposes, adopted strategies similar to the NCAI and sought to capitalize on the tension between provisionality and colonial difference. The discursive combination of underdevelopment and foreignness during the early Cold War provided sites of strategic negotiation through which specific groups-including American Indians, Puerto Ricans, and Southwestern Hispanos - claimed political and economic resources from the U.S. state. The outcome of such negotiations partially depended upon each group's respective status with regard to the historical conditions of U.S. colonialism and the shifting dynamics of the Cold War. At the same time, the past and present of U.S. colonialism were categorically excluded from the mid-twentieth-century liberal discourse of the foreign, and in fact marked the limit of its capacity to assimilate difference as a provisional form remedied by the advance of the United States as leader of the "free world."

\section{LOCATING “UNDERDEVELOPMENT"}

Conventional accounts of U.S. history often compartmentalize the politics of poverty. Accordingly, throughout the 1950 s poverty was an international problem framed by the problem of underdevelopment and, during the 1960s, it was a domestic issue defined in terms of opportunity. In his 1949 inaugural address, President Harry S. Truman outlined a plan to extend U.S. foreign assistance through technical aid for "the improvement and growth of underdeveloped areas." World poverty, according to Truman, was of particular concern because "the economic life [of the poor] is primitive and stagnant ... Their poverty is a handicap and a threat both to them and to more prosperous

\footnotetext{
${ }^{3}$ Walter Mignolo, Local Histories/Global Designs: Coloniality, Subaltern Knowledges, and Border Thinking (Princeton: Princeton University Press, 2000).
} 
areas."4 Significantly, whether underdeveloped or prosperous, "area" in this sense was synonymous with nation-state. Only with the 1957-1958 economic recession did this concern for the political and economic repercussions of poverty begin to officially translate to the United States. The 1964 Economic Opportunity Act consummated a domestic policy concern with poverty as distinct from and a menace to the norms of U.S. liberal democracy. That same year, in its report to the President, the Council of Economic Advisors (CEA) warned that "Poverty is costly not only to the poor but to the whole society... It is a social and a national problem." The CEA worried - in language echoing Michael Harrington's Other America and subsequently recast in racial terms by the 1968 Kerner Commission - that "The poor inhabit a world scarcely recognizable, and rarely recognized, by the majority of their fellow Americans. It is a world apart, whose inhabitants are isolated from the mainstream of American life and alienated from its values."

The idea that poverty was in some fundamental way a question of culture had particular salience within this shift. The Cold War established the terms through which "the poor" were constituted as a distinct and singular social group with a discernable culture and psychology to be studied. Poverty was not a consequence of capitalist market relations but rather a lack of attachment to the capitalist economy. The postwar ascendancy of the behavioral sciences focused attention on the family as the crucible of culture and personality, and isolated psychological dynamics from social and economic conditions. During the Cold War, social scientists set about enumerating the psychological traits that they argued personified a distinctive "national character." American character was supposedly orientated towards achievement, acquisition, individualism, and deferred gratification in the service of long-term objectives. This psychological-cultural explanation for affluence and American exceptionalism positioned poor people in the United States as foreign to white middle-class familial norms and lacking national character. ${ }^{6}$

Underdevelopment, moreover, was not conceptually incidental to the Cold War. U.S. policymakers promoted a specific social, cultural, and political worldview in their efforts to stabilize and expand capitalist markets. The Marshall Plan aimed to re-establish political and economic stability in Western Europe and Japan and to provide a bulwark against communist encroachment. The Point Four program expanded on this precedent, promoting the "disinterested" reason of technical assistance as a means for the

4 President Harry S. Truman's inaugural address, 20 Jan. 1949. Excerpted as “The President's Proposal" in, Walter M. Daniels, ed., The Point Four Program, (New York: H. W. Wilson Company, 1951).

5 Economic Report of the President, with The Annual Report of the Council of Economic Advisors (Washington, D.C.: Government Printing Office, 1964), 55.

6 Alice O'Connor, Poverty Knowledge: Social Science, Social Policy, and the Poor in TwentiethCentury U.S. History (Princeton: Princeton University Press, 2001), 99-123. 
comprehensive re-education of strategically selected countries with limited industrial and market infrastructures. The development paradigm was a product of eighteenth-century Enlightenment thought, but the economic logic broached at Bretton Woods in 1944 and advanced by Point Four in 1949 defined the specific conditions through which development and underdevelopment became organizing principles for the Cold War. According to political theorist Timothy Mitchell, "the development of the economy as a discursive object between the 1930s and 1950s provided a new, everyday political language in which the nation-state could speak of itself and imagine its existence as something natural, spatially bounded, and subject to political management." Notions of the modern economy as a self-evident totality underwrote an emergent conception of the nation-state and its indispensable role in economic growth measured by such abstractions as "gross national product." This new perspective, consistent with the consolidation of "national history," provided a geo-spatial representation of global economic relations "in which the world was pictured in the form of separate nation-states, with each state marking the boundary of a distinct economy." "Former United Nations Development Program administrator Majid Rahnema argues that with this epochal shift "entire nations ... [came] to be considered (and consider themselves) as poor."

For many U.S. policymakers after World War II, underdevelopment was increasingly described as an identifiable collection of cultural deficiencies shaped in isolation from the capitalist marketplace. From this vantage point, underdevelopment could be remedied through the disciplining procedures of capitalism, measures that were not simply economic but also cultural. Modernization theorists enthusiastically adapted Weber's cultural analysis of capitalist development through the lens of Talcott Parsons, who conveniently discarded Weber's unfavorable assessment of modernity itself, to prescribe normative cultural change. " Anthropologist Oscar Lewis" "culture of poverty" subsequently delineated an inherited assemblage of personality traits used by many social scientists and policymakers during the 1960 s to justify marketoriented remediation. Lewis' "culture of poverty," like George Orwell's phrase "Cold War" and Alfred Sauvy's "Third World," was initially a critical description of prevailing power relations. Mainstream discourse transformed

\footnotetext{
7 Timothy Mitchell, "Origins and Limits of the Modern Idea of the Economy" (MS, Workshop on Positivism and Post-Positivism, University of Chicago, Oct. 2001). Quotations are from pages 18-19, 20, 22. Also see Hugo Radice, “The National Economy: A Keynesian Myth?” Capital and Class 22 (1984): 111-40; and Mitchell's "Economists and the Economy in the Twentieth Century" in, George Steinmetz, ed., The Politics of Method in the Human Sciences: Positivism and Its Epistemological Others (Durham: Duke University Press, 2005).

8 Majid Rahnema, "Global Poverty: A Pauperizing Myth," Interculture 24, 2 (1991): 4-51. Arturo Escobar elaborates on Rahnema's claims in Encountering Development: The Making and Unmaking of the Third World (Princeton: Princeton University Press, 1995).

9 Nils Gilman, Mandarins of the Future: Modernization Theory in Cold War America (Baltimore: Johns Hopkins University Press, 2003), 92-94.
} 
and "de-polemicized" the meaning of each of these terms. Although Lewis intended his term to highlight the generational survival strategies of poor people, most social scientists and policymakers using the notion of a culture of poverty focused on cataloging behaviors that defined as passive, apathetic, impulsive, and reprehensibly deviant specific —often racialized-groups of poor people. ${ }^{10}$ Building on this inverted account, U.S. policymakers and social scientists extricated the "culture of poverty" from the circumstances of capitalist exploitation and reframed the problem of poverty as poor people's lack of integration into normative capitalist society. Defined as a discrete culture, poverty could be understood as inherently foreign to liberal American values. Indeed, here underdevelopment served as a teleological mandate for the benevolent import of U.S. liberal capitalism.

In order to strategically claim underdevelopment, groups occupying the incriminating grounds of U.S. territorial conquest had to contend with a number of legal and political precedents. In 1831, for instance, U.S. Supreme Court Chief Justice John Marshall's ruling on Cherokee Nation v. Georgia invented for American Indian tribes the new legal category "domestic dependent nations" in an effort to undermine their sovereignty and rationalize the economic and political needs of U.S. expansionism. In the Southwest, the 1848 Treaty of Guadalupe Hidalgo finalized the vast seizure of Mexican territory in the settlement of the U.S.-Mexican War and conferred upon annexed Mexican nationals U.S. citizenship rights-provided that they relinquish their Mexican "character" (which by implication was racial as well as nationalcultural). At the turn of the twentieth century a series of constitutional decisions produced the Insular Cases in response to the national controversy over the status question of the territories acquired through the 1898 defeat of Spain. The doctrine of "unincorporation" was adopted in an effort to resolve the messy business of U.S. colonialism. This doctrine was a means of establishing the essential difference of the peoples of those unincorporated territories, while still proclaiming U.S. jurisdiction and control over them. ${ }^{11}$

\footnotetext{
${ }^{10}$ Lewis first proposed his "culture of poverty" thesis in Five Families: Mexican Case Studies in the Culture of Poverty (New York: Basic Books, 1959). O’Connor's Poverty Knowledge provides a nuanced reading of the "culture of poverty" thesis and its subsequent uses.

11 On Cherokee Nation v. Georgia and the history of United States-American Indian treaties, see Vine Deloria, Jr., Behind the Trail of Broken Treaties: An Indian Declaration of Independence, 2d ed. (Austin: University of Texas Press, 1985); and Glenn T. Morris, "Vine Deloria, Jr., and the Development of a Decolonizing Critique of Indigenous Peoples and International Relations" in, Richard A. Grounds, George E. Tinker, and David E. Wilkins, eds., Native Voices: American Indian Identity and Resistance (Lawrence: University of Kansas Press, 2003). On the Insular Cases and the legal construction of the "unincorporation," see Christina Duffy Burnett and Burke Marshall, eds., Foreign in a Domestic Sense: Puerto Rico, American Expansion, and the Constitution (Durham: Duke University Press, 2001). On the disputed legacy of the Treaty of Guadalupe Hidalgo, see Richard Griswold del Castillo, The Treaty of Guadalupe Hidalgo: A Legacy of Conflict (Norman: University of Oklahoma Press, 1990). For insights into the racialized terms of the Treaty see María Josefina Saldaña-Portillo, "“Wavering on the Horizon of Social Being': The Treaty
} 


\section{REFRAMING ACCOUNTABILITY}

With policymakers historically intent on making absent the question of U.S. colonialism and Cold War geopolitics decisively shifting to the so-called periphery, Truman's Point Four program deliberately projected the conditions of underdevelopment abroad. However, the emphatically universal promise of the development paradigm left open other unforeseen possibilities.

In 1951, D'Arcy McNickle, chairman of the Indian Tribal Relations Committee of the National Congress of American Indians (NCAI), proposed a tenpoint plan targeting Indian poverty modeled on Truman's foreign technical assistance program. McNickle's domestic Point Four program emphasized the role of self-help and increased federal appropriations for Indian reservations. His proposal however met with little success. ${ }^{12}$ Two years later, the 83rd Congress adopted House Concurrent Resolution 108 to terminate federal trusteeship of Indian reservations. Beginning in the mid-1940s, a concerted backlash against the Indian Reorganization Act of 1934 attempted to undo the so-called "retribalization" promoted by Commissioner of Indian Affairs John Collier. Culminating in the 1953 legislation, federal termination policy sought rapid and total assimilation for Indians into dominant white society. Termination also mandated a stepped-up effort to seize valuable tribal land and natural resources for non-Indian private industry through the selling off of "surplus" property in excess of the designated allotments to individual Indians. The National Congress of American Indians was founded in 1944 largely as a response to the emergent threat of termination. As the only national intertribal organization at the time, the NCAI was in a unique position during the 1950s to campaign against termination policy. ${ }^{13}$

In 1953, McNickle reasserted the parallel between U.S. domestic and foreign underdevelopment. "Surely the United States," he insisted, "which would like to see undeveloped and under-developed areas of the World brought into more

of Guadalupe-Hidalgo and the Legacy of Its Racial Character in Paredes' George Washington Gómez," Radical History Review 89 (Spring 2004): 135-64.

12 D'Arcy McNickle, “A Ten-Point Program for American Indians," National Congress of American Indians, 1951 Convention, St. Paul, Minn. (Conventions and Mid-Year Conferences, Speeches 1951; NCAI, Conventions, 1950-1953, Box 3; National Anthropological Archives, Smithsonian Institution, Washington, D.C. [hereafter NAA]). On federal termination policy, see Donald L. Fixico, Termination and Relocation: Federal Indian Policy, 1945-1960 (Albuquerque: University of New Mexico Press, 1986); Vine Deloria, Jr. and Clifford M. Lytle, The Nations Within: The Past and Future of American Indian Sovereignty (Austin: University of Texas Press, 1998 [1984]); Kenneth R. Philp, Termination Revisited: American Indians and the Trail to SelfDetermination, 1933-1953 (Lincoln: University of Nebraska Press, 1999); and David E. Wilkins and K. Tsianina Lomawaima, Uneven Ground: American Indian Sovereignty and Federal Law (Norman: University of Oklahoma Press, 2001).

13 For a history of the NCAI between 1944 and 1961, see Thomas W. Cowger, The National Congress of American Indians: The Founding Years (Lincoln: University of Nebraska Press, 1999). 
fruitful functioning, is capable of achieving the development of its own native population."14 During its annual convention the following year in Omaha, Nebraska, the NCAI put forward another proposal largely derived from McNickle's earlier plan. ${ }^{15}$ The proposal was submitted to the U.S. Congress as the Point IX Program (one point of McNickle's list of ten having been resolved during the intervening years), again deliberately invoking U.S. technical assistance abroad as an alternative model to forced termination. The text of the proposal asserted Indian autonomy while also stipulating specific rights with regard to U.S. society originating from the historical conditions of colonization: "this program shall be offered to the American Indian communities without exacting termination of the federal protection of Indian property or of any other Indian rights as its price; that Indian culture and identity shall not be restricted or destroyed; that technical guidance and financial assistance shall be made available; that the request for assistance shall come from the Indians themselves after each Indian group has studied itself in terms of its own needs."16 The terms outlined by the proposal replicated the language supporting technical assistance to impoverished nations abroad, where U.S. policymakers' focus on technical support and the expansion of industry and market relations was combined with an emphasis on national self-determination in order to attract the participation of newly decolonized states.

Confronted with a coalition of influential legislators and a small but vocal group of pro-termination Indians, the NCAI's Point IX Program was never implemented. Undaunted, the NCAI worked to generate publicity in support of its campaign against termination. With this objective, it organized a fourteenmember delegation to travel to Puerto Rico in March 1958 to learn about "Operation Bootstrap," the island's highly touted program for industrialization. The Muñoz administration in Puerto Rico had succeeded in rallying diplomatic and economic support from Washington for its newly established "free associated state" status and in generating international attention for its role as a U.S. State Department showcase. Muñoz's Partido Popular Democrático used the Point Four program to push the legal logic of the Insular Cases to their limit by insisting upon being "foreign in a domestic sense" in such a way as to most benefit from this alliance while also securing the greatest possible political autonomy. As stated in a February 1958 NCAI announcement to its membership, in addition to continuing the organization's efforts to cultivate a Point Four approach to developing "human and natural resources in Indian communities," the trip would be valuable for understanding the ways in which "The Puerto Rican people in the last twenty years have learned much about public

14 D’Arcy McNickle, “U.S. Indian Affairs-1953,” América Indígena 13 (Oct. 1953): 273.

${ }_{16}$ Cowger, The National Congress of American Indians, 108-9, 117.

16 As quoted in Harold E. Fey and D'Arcy McNickle, Indians and Other Americans: Two Ways of Life Meet (New York: Harper \& Brothers, 1959), 198. 
relations, about getting great men to champion their cause, about bringing about community development."17

The NCAI leaders believed much could be gained from the trip. As with the visitors and diplomats that streamed into Puerto Rico from Africa, Asia, the Middle East, and Latin America, NCAI leaders thought there was something in the Puerto Rican model applicable to their own situation. American Indians, perhaps more than visitors from the formerly colonial world, could look to Puerto Rico for lessons in negotiating and transforming an ongoing colonial predicament. Their sojourn was thus equal parts publicity endeavor and informational tour. For one week they toured new production facilities, visited community development projects, and met with various officials. ${ }^{18}$ Upon their return, NCAI representatives sought to implement lessons learned. They hired the public relations firm Sontheimer-Runkle, which also represented the Commonwealth of Puerto Rico in the United States. ${ }^{19}$ More importantly, they proposed legislation entitled "Operation Bootstrap for the American Indian" that succeeded in prompting Congressional hearings in 1960.

During these hearings, non-Indian politicians demonstrated considerable support for programs geared towards tribal economic development. Nebraska Congressman Lawrence Brock emphasized the inefficiency of the current situation, testifying, "For the good of this Nation, with its present tensions and international problems, it seems a sacrilege not to utilize the now terrible waste of human resources on the Indian lands. ... Now is the time to do something material and constructive to put those many thousands of idle hands into a production program, one that will return material and lasting benefit to a nation that owes something to the American Indian." ${ }^{20}$ Co-sponsor of the bill, South Dakota Representative E. Y. Berry, detailed economic incentives and tax abatements modeled on the Puerto Rican case to encourage private investment and industrial development in Indian reservations. Testimonies promoted reservation industrialization as an untapped business opportunity with the distinct benefit of operating outside of U.S. regulatory standards and minimum wage laws while still being insured by federal enticements and oversight.

NCAI delegates and other tribal representatives, however, were not solely concerned with attracting capital investment and imported industry. Instead

\footnotetext{
17 “Announcement of Opportunity to Study 'Operation Bootstrap' in Puerto Rico,” 12 Feb. 1958 (National Congress of American Indians-Puerto Rico Study Trip [Operation Bootstrap 19561958]; NCAI Fundraising, Box 6, NAA).

18 "Misión de los Pueblos Indios de Norteamérica en Puerto Rico," El Mundo, 6 Mar. 1958; Ramon M. Diaz, "Muñoz Va A Congreso De Indios," El Imparcial, 6 Mar. 1958.

19 John Fahey, Saving the Reservation: Joe Garry and the Battle to Be Indian (Seattle: University of Washington Press, 2001), 123.

${ }^{20}$ Cowger, The National Congress of American Indians, 122-23; House Committee on Interior and Insular Affairs, Operation Bootstrap for the American Indian: Hearings Before the Subcommittee on Indian Affairs, H.R. 7701, 8803, and 8590, 86th Congress, 2d Session (Washington, D.C.: Government Printing Office, 1960), 27.
} 
they clearly articulated political and cultural concerns as inseparable from economic development. Allen Quentone, a Kiowa tribal member who had traveled to Puerto Rico with the NCAI, affirmed that such a plan "must provide many alternatives for development, and that encouragement to find better solutions to Indian problems should begin in economic and social areas before there is any more headlong rushing into changing the political status of Indians." ${ }^{21}$ NCAI Executive Director Helen Peterson highlighted the importance of Puerto Rican initiatives in community development that worked in conjunction with the industrialization program. Peterson testified, "We hope that the Congress ... will not only enact the bills under consideration with amendments, but will continue to do those other things that go along with industrial development that may make for the kind of progress among American Indians that has been possible and that we have seen achieved in Puerto Rico in 20 years." 22 American Indian political and cultural self-determination were forcefully reasserted as essential to any program for economic development. In direct opposition to termination legislation, Indian testimony argued for preserving a U.S. presence that upheld past treaties and responsibilities while strengthening Indian independence.

Although the bill itself was not passed, the federal government's efforts to pursue a policy of termination dissipated. During the second half of the 1960s and throughout the 1970s, a growing number of organizations built on and extended the NCAI's intertribal work for economic and political selfdetermination without relinquishing U.S. government responsibilities, and some advanced a decidedly more radical and confrontational stance. Within this context, the Nixon administration espoused the language of tribal "selfdetermination" and the U.S. Congress made overtures to accommodate and contain Indian pressure for change. In his proposal "A Plan for Navajo Economic Development," prepared for the 1969 Congressional study Toward Economic Development for Native American Communities, anthropologist David Aberle asserted, "The argument set forth here is that the Navajo country is an underdeveloped area, and that the cause of its underdevelopment is its historical and current relations with the larger polity, economy, and society." He prodded the federal government to commit economic resources and technological support to the Navajo Nation, but insisted that the Navajos have independence in the planning and management of development projects. ${ }^{23}$ During this period, many tribes and intertribal groups went beyond calls for economic development to demanding access to financial support and

21 Operation Bootstrap, 77.

22 Operation Bootstrap, 81.

23 U.S. Congress Joint Economic Committee, Toward Economic Development for Native American Communities, vol. 1 (Washington, D.C.: Government Printing Office, 1969), 236. 
investment — controlled by tribes themselves - that respected their economic, cultural, and political autonomy. ${ }^{24}$

THE DISCOMFORT OF STRANGERS

The mission of the Peace Corps appears at first to confirm U.S. policymakers' view of underdevelopment as a problem for places elsewhere. The agency's field training initiatives, however, insisted upon identifying a foreignness closer in proximity. Although this affirmed none of the causal relations that David Aberle insisted upon with regard to the Navajo situation, it did potentially authorize multiple claims in the name of underdevelopment.

In 1957, Wisconsin Congressman Henry S. Reuss returned from a trip to Cambodia worried about U.S. credibility among formerly colonized nations. Reuss recommended establishing a program to send young American volunteers to these countries as a demonstration of U.S. goodwill. Such a program would provide technical staffing for U.S. foreign aid projects, convey American ideals and aspirations to the peoples of other nations through direct contact with American youth, and provide a sense of purpose and inspiration for volunteers themselves. ${ }^{25}$ Reuss and Oregon Senator Richard Neuberger cosponsored a bill to create a "Point Four Youth Corps." Although the project received limited congressional support, the idea of dedicated American youth engaged in the "shirtsleeve diplomacy" of technical assistance abroad generated a good amount of favorable publicity. Three years later, Hubert Humphrey included the idea, now dubbed the "Peace Corps," as a part of his brief presidential campaign, passing on the details of his plan to John F. Kennedy upon withdrawing from the race. For Kennedy, the Peace Corps idea offered a tangible demonstration of how youth inspired by his call to service might serve their country and the world at large simultaneously. It was thus an idea addressed to Kennedy's belief in the strategic importance of the Third World for U.S. policy, while also embodying the youthful idealism and higher purpose with which his administration was eager to be associated. ${ }^{26}$

In 1961, after the agency had been formally established, Peace Corps administrators began to consider the question of training its volunteers as a first step in getting the initiative underway. A central training concern expressed by administrators was the issue of volunteer adjustment to cultural differences abroad.

\footnotetext{
24 Roxanne Dunbar Ortiz, ed., Economic Development in American Indian Reservations (Albuquerque: University of New Mexico Native American Studies Development Series 1, 1979); Dean Howard Smith, Modern Tribal Development: Paths to Self-Sufficiency and Cultural Integrity in Indian Country (Walnut Creek: AltaMira Press, 2000); Brian Hosmer and Colleen O'Neill, eds., Native Pathways: Indian Culture and Economic Development in the Twentieth Century (Boulder: University Press of Colorado, 2004).

${ }^{25}$ Henry S. Reuss, "A Point Four Youth Corps" in Pauline Madow, ed., The Peace Corps (New York: H. W. Wilson Company, 1964), 12.

26 Gerald T. Rice, The Bold Experiment: JFK's Peace Corps (Notre Dame: University of Notre Dame Press, 1985), 10-12.
} 
They turned to the concept of "culture shock" as the principal construct through which to address this concern. ${ }^{27}$ During the mid-1950s, as U.S. enterprise rapidly expanded abroad, managers, educators, and social scientists gave increasing attention to the problems they believed confronted businessmen, diplomats, and students working outside the United States. With funding from the Carnegie Corporation, Harlan Cleveland, Dean of the Maxwell School at Syracuse University and future Assistant Secretary of State, co-authored and edited two influential books on the topic, The Art of Overseasmanship (1957) and The Overseas Americans (1960). ${ }^{28}$ The latter, especially, highlighted "culture shock" and the importance of "cultural empathy," and became part of the core curriculum of Peace Corps training.

The conceptual framework of culture shock relied upon liberal universalist constructions of the foreign. On one hand, culture shock was predicated on the assumption that the foreign precipitated a confrontation with absolute difference beyond recognition. On the other, it served as a means of assimilating and comprehending this difference. Cultural empathy provided a transitional means of negotiating this disconcerting encounter, and elevating "overseas Americans" to a universal vantage point above the fray of unfamiliarity.

The term "culture shock" had been coined during the mid-1950s by Kalervo Oberg, an anthropologist affiliated with the U.S. International Cooperation Administration mission in Brazil. Oberg defined "culture shock" as a psychological condition "precipitated by the anxiety of losing all our familiar signs and symbols of social intercourse. These signs or cues include the thousand and one ways in which we orient ourselves to the situations of daily life ..." Oberg provided a list of apparently quotidian examples: "when to shake hands and what we say when we meet people, when and how to give tips, how to give orders to servants, how to make purchases, when to accept and when to refuse invitations, when to take statements seriously and when not." 29 That such concerns applied both to the U.S. diplomats, who were the audience for Oberg's initial observations, and Peace Corps volunteers speaks to the presumed class privilege of both. When stripped of familiar convention, these preoccupations with and anxieties over etiquette and class position apparently assumed traumatic proportion. The Peace Corps sought to develop distinct instructional methods to counteract the disorientations of culture shock

\footnotetext{
27 Indeed, historian Elizabeth Cobbs Hoffman has commented, "The Peace Corps brought into the American lexicon a new term — culture shock — which it did not invent but certainly helped to popularize." All You Need Is Love: The Peace Corps and the Spirit of the 1960s (Cambridge, Mass.: Harvard University Press, 1998), 134.

28 Harlan Cleveland and Gerard J. Mangone, eds., The Art of Overseasmanship (Syracuse: Syracuse University Press, 1957); and Harlan Cleveland et al., The Overseas Americans (New York: McGraw-Hill, 1960).

${ }^{29}$ Kalervo Oberg, "Culture Shock: Adjustment to New Cultural Environments," Practical Anthropology 7, 4 (July-Aug. 1960): 177-82. This essay originally appeared in the State Department's Technical Assistance Overseas Bulletin.
} 
and provide its volunteers with the means of maintaining a confident, if empathetic, posture abroad. ${ }^{30}$ Descriptions of culture shock moved easily between cultural and economic registers in Peace Corps literature. In training materials, accounts of culture shock often described the trainee's shock at conditions of abject poverty as an encounter with cultural difference. Similarly, culture shock conflated culture and poverty such that Peace Corps Volunteers, as ostensible models of ingenuity and fortitude, were deemed agents of change simply by the cultural example they provided.

One initial purpose of field training was to provoke culture shock. Staging this trauma prior to selecting volunteers for assignments overseas would both minimize the emergence of its later more damaging effects abroad and allow monitoring of trainees as they passed through Oberg's stages towards reestablishing psychological equilibrium. ${ }^{31}$ Agency planners supposed an intrinsic parallel between culturally unfamiliar poor communities in the United States and impoverished countries abroad, and looked for U.S. contexts to simulate foreign conditions.

An early example of this approach to training was Columbia University's placement of volunteers in New York City social work offices in poor Spanishspeaking neighborhoods. ${ }^{32}$ Affirming the presumptions of the new training regime, one Columbia University trainee testified, "The most valuable part of my field work experience has been what one might call a cushion in preparation for a cultural shock. The experience has, to a large extent, been a shock and opened my eyes to the realities of city life that I had not known before. I am sure that I will encounter similar shock in Colombia but now I feel much better prepared to meet it."33

Numerous other locations facilitated and repeated this experience. The Waipio Valley in Hawai'i, for instance, provided a "remote tropical" and "exotic" location where trainees bound for Indonesia, the Philippines, and other regions of the Far East learned to grow rice and taro and build thatched huts. ${ }^{34}$

30 Charles B. Arnold, "Culture Shock and a Peace Corps Field Mental Health Program," Community Mental Health Journal 3, 1 (Spring 1967): 53-60. Also see Robert B. Textor, ed., Cultural Frontiers of the Peace Corps (Cambridge, Mass.: MIT Press, 1966).

31 On the centrality of psychological thought as a normative framework in mid-twentieth-century U.S. thought, see Steven C. Ward, Modernizing the Mind: Psychological Knowledge and the Remaking of Society (Westport, Conn.: Praeger, 2002).

32 Mitchell Ginsberg, "Short-Term Training for the Peace Corps," Social Work (Jan. 1964): 6268; Gertrude Samuels, "Peace Corps Trains in New York," New York Times, 21 Oct 1962: 252; "Peace Corps Trainees Work, Study in New York Slums," Peace Corps Volunteer 1, 1 (Nov. 1962): 1 .

33 Quoted in Ginsberg, "Short-Term Training," 65.

34 Characterization quoted from George Sullivan, The Story of the Peace Corps (New York: Fleet Publishing, 1964), 64-65. Regarding how certain sectors of Hawaì encouraged field training on the islands, see "Concurrent Resolution of Hawaii Legislature Relating to Peace Corps," Congressional Record 107, 4 (1961): 4849; and David L. Englund, "Peace Corps Training and the American University," International Review of Education 11, 2 (1965): 209-17. 
Training simulation fit well with the overall posture of the Peace Corps as a noble experiment of motivated U.S. youth "living poor" and voluntarily sharing the conditions of austerity and deprivation of those struggling peoples they went to serve abroad. ${ }^{35}$ It also complemented what historian Michael Latham has described as the Peace Corps' dual mission to make international role models of American youth, and, in the context of Kennedy's New Frontier, to rejuvenate and regenerate the volunteers themselves through a rediscovery of the Turnerian frontier as a crucible for the American character. ${ }^{36}$

\section{BETWEEN THE FOREIGN AND THE FAMILIAR}

Among the most extensive and enduring of these programs was the University of New Mexico's Peace Corps Training Center, one of only four year-round Peace Corps training contracts. Writing UNM's proposal for training Peace Corps volunteers slated to serve in Latin America, UNM professor and future training center director Marshall Nason argued that New Mexico offered an exemplary context for training because it provided a "state-wide laboratory" and was "itself an underdeveloped area" with "people speaking Spanish and Indian languages as well as English." Nason surmised, "the populations of many Latin American countries are also composed in a large part of indigenous peoples. Many of these countries, therefore, have Indian problems much like those found in the Southwestern United States." Similarly, in his letter confirming arrangements with the Peace Corps, University President Tom Popejoy emphasized "the unique features of New Mexico-its combination of cultures, its islands of primitive peoples and underdeveloped communities, its first-hand experience with problems of cultural adaptation in the process of economic development."37

If notably facile, as well as patronizing toward New Mexico's impoverished Hispanos and American Indians, Nason's and Popejoy's characterizations of New Mexico were nonetheless in keeping with contemporary social science

35 The reference here is to Moritz Thomsen's memoir Living Poor: A Peace Corps Chronicle (Seattle: University of Washington Press, 1969), which is emblematic of a number of laudatory Peace Corps volunteer memoirs published during the 1960s.

36 Michael Latham, Modernization as Ideology: American Social Science and "Nation Building" in the Kennedy Era (Charlottesville: University of North Carolina Press, 2000), 144-46. Sargent Shriver, reiterating the conventional interpretation of Frederick Jackson Turner's "frontier thesis," insisted, "the Peace Corps is truly a new frontier in the sense that it provides the challenge of self-reliance and independent action which the vanished frontier once provided on our own continent. Sharing in the progress of other countries helps us to rediscover ourselves at home" (in Latham, Modernization as Ideology, 145).

37 "A Proposed Training Center for Peace Corps Personnel, The University of New Mexico, Albuquerque, New Mexico, April 10, 1961," 1-2, Box 1; and Tom L. Popejoy, President, UNM, letter to Dr. Joseph Kauffman, Chief, Training Program, Peace Corps, Washington, D.C., 2 June 1962, Colombia III Training Proposal 1962, Box 8, Peace Corps Collection, Center for Southwest Research, General Library, University of New Mexico, Albuquerque [hereafter PC/ CSWR]. 
estimations of the state. Anthropologist Margaret Mead had recently published the UNESCO-sponsored Cultural Patterns and Technical Change, in which she included New Mexico's Spanish Americans along side Burma, Greece, the Palau Islands, and the Tiv people of Nigeria as case studies on the cultural impact of technological modernization on "underdeveloped" societies. ${ }^{38}$ In 1962, sociologist Clark Knowlton observed, "In the past few years New Mexico has reached a position comparable to many underdeveloped countries in the world." He stressed that "rapid social and cultural changes are bringing with them rising rates of welfare and dependency, family breakdown, juvenile delinquency, the creation of chronically depressed areas, large scale population movements, and cultural breakdown among minority groups." Concluding that New Mexico's economy was "a colonial economy in every sense of the word," Knowlton speculated, "If these distressed areas had the good fortune to be located in Africa, Asia, or Latin America, they would be the recipients of foreign aid, peace corps groups, and a concerted effort to resolve their problems." 39

Indeed, in many respects the history of New Mexico presents a striking chronicle of conquest, resistance, and colonization. This history is remarkable even if we only consider the period since the U.S.-Mexico War. Following the territory's seizure, Congressional fears of its mixed-race population eroding U.S. Anglo-Saxon predominance served to postpone admission into the Union. In 1850, New Mexico — which included Arizona at that time - was formally designated a U.S. territory, ruled by Congress and without political representation. Despite sustained petitioning for statehood, New Mexico was not admitted into the Union until 1912. With the complicated exception of Puerto Rico, this sixty-two year interval between territorial status and statehood remains unsurpassed in U.S. history. Between 1902 and 1912, Senator Albert Beveridge, chairman of the Senate Committee on Territories, became well known for his unflagging efforts to maintain the territory's unincorporated subordinate status. During subcommittee hearings on the matter, he harped incessantly on the racial composition of New Mexicans as well as their persistent use of the Spanish language. Notably, racial categories themselves were in flux in New Mexico, where elite Hispano families sought to claim whiteness in distinction from the mixed-blood poor and Indians, and the demographic

38 Margaret Mead, Cultural Patterns and Technical Change (New York: Mentor Books, 1955), 151-77. The cover text on the Mentor popular press edition read: "An exciting voyage to distant lands where century-old methods of ancient people give way to the most modern machines and techniques mankind has devised" (my emphasis).

39 Clark S. Knowlton, "Area Development in New Mexico: Implications for Dependency and for Economic and Social Growth," New Mexico Conference of Social Welfare, 1961-1962 (Clark S. Knowlton Collection, Box 33, Folder 8, New Mexico State Records Center and Archives, Santa Fe), 2, 4. 
disadvantage of Anglos fostered widespread intermarriage and racial accommodation in the service of class. ${ }^{40}$

By the time of University of New Mexico's proposal for Peace Corps training, the Hispano villages and Indian pueblos of north central New Mexico had already been subject to a long history of Anglo fascination and intrusion. By the mid-twentieth century, the descendants of Spain's sixteenth-century conquest and late-seventeenth-century re-conquest of the region remained a relatively close-knit group of townships living on properties collectively held through Spanish and Mexican land grants. An influx of early-twentieth-century anthropologists in the region had during the 1920s and 1930s been supplemented by Anglos who sought to recapture the supposed pre-modern authenticity of rural village life. ${ }^{41}$ The 1930 s craft revival celebrated both Spanish colonial and pueblo traditions and began to integrate artisanal labor into expanded market relations. However, indigenous forms of community organization were often either romanticized by Anglo settlers, or, through the lens of postwar community development, incorporated only to the degree indigenous methods and institutions were recognizable and amenable. ${ }^{42}$

In order to recruit prospective community participation, UNM launched a publicity campaign that included contacting city councils, local officials, civic organizations, and local professional groups. Historically entrenched divisions of power and resources not only characterized the places where training took place, but often determined who in a given town or area initiated contact with UNM's Training Center. ${ }^{43}$ For example, one account of an early planning meeting in the town of Chama notes, "The meeting hall was quickly filled before eight o'clock with about sixty of what might be termed 'middle-class' - businessmen, teachers, etc. - of Chama. Both the Spanish-American and the Anglo segments seemed to be equally represented. Conspicuously absent were the Negro of which Chama had a small but noticeable percentage." Another report describes an irrigation project started but eventually abandoned because it had been initiated by an Anglo rancher with a vested interest but no support from the majority Hispano members of the town. ${ }^{44}$ To a certain extent,

40 Erlinda Ganzales-Berry and David R. Maciel, eds., The Contested Homeland: A Chicano History of New Mexico (Albuquerque: University of New Mexico Press, 2000); and Charles Montgomery, The Spanish Redemption: Heritage, Power, and Loss on New Mexico's Upper Rio Grande (Berkeley: University of California Press, 2002).

41 Suzanne Forrest, The Preservation of the Village: New Mexico's Hispanics and the New Deal, 2d ed. (Albuquerque: University of New Mexico Press, 1998).

${ }^{42}$ See, for instance, José A. Rivera, Acequia Culture: Water, Land and Community in the Southwest (Albuquerque: University of New Mexico Press, 1998).

43 John H. Burma and David E. Williams, An Economic, Social and Educational Survey of Rio Arriba and Taos Counties (E1 Rito, N.M.: Northern New Mexico College, 1960) provides contemporary data on the complexity of class and ethnic relations in the area.

44 "The Entrance of C.D. into Northern New Mexico Communities," Mar.-Apr. 1963, Box 4, $\mathrm{PC} / \mathrm{CSWR}$. 
the abstract universalism of Peace Corps training discourse could accommodate such conflicts. After all, it was exactly this sort of fractured civic engagement that volunteers would mend abroad. However, the Peace Corps Training Center's solicitations, even as they purportedly sought out community involvement, remained focused on officially sanctioned institutional representatives.

Toward the end of the 1950s and throughout the 1960s, long-standing and often violent Hispano land grant struggles in north central New Mexico intensified. Actions by the U.S. government and judicial system had consistently denied the region's Spanish American families the territorial rights guaranteed in the Treaty of Guadalupe Hidalgo. During the late nineteenth century, government surveyors, local Anglo banks and ranchers, and real estate speculators such as Thomas B. Catron, defrauded land grantees out of thousands of acres of land. Furthermore, in violation of the Treaty, the government refused to recognize the communal system of land tenure formalized in the land grants. During the early 1960s, the National Forest Service, perceived by many Hispanos as an occupying army terrorizing their communities, had stepped up efforts to drive farmers off of disputed properties and rescind grazing rights on land deemed to be in the public domain. To add insult to injury, just as the displacement of Hispano farmers accelerated, the Forest Service was busy transferring use rights for these same territories to corporate timber and agriculture interests.

In 1963, the grassroots organizing efforts of Reies López Tijerina and local Hispanos created the Alianza Federal de Mercedes (Federated Alliance of Land Grants). As with the campaign by National Congress of American Indians, the Alianza framed their land claims in explicitly international terms that highlighted U.S. continental colonization and imperialism. Alianza pamphlets brazenly announced that the "USA is trespassing in New Mexico." In 1964, Tijerina began planning a two-hundred-car caravan to Mexico City to publicize the Alianza's efforts and request that Mexican President Adolfo López Mateos submit to the United Nations formal charges against the United States for violating the Treaty of Guadalupe Hidalgo. While Tijerina was in Mexico making arrangements for the caravan he was arrested by undercover Mexican police-most likely working in conjunction with U.S. agencies - and deported back to the United States. During October 1966, members of the Alianza occupied the Echo Amphitheater area of the Kit Carson National Forest, a section of the territory included within the San Joaquín del Río Chama land grant. Here they proclaimed the autonomous Republic of the Pueblo San Joaquín del Río Chama, and hoisted their national flag of blue and gold. Although this episode - and others such as when in 1967 armed Aliancistas stormed the Tierra Amarilla county courthouse to forcibly depose and arrest district attorney Alfonso Sánchez for his ongoing harassment of land grant activists - proved unsuccessful in achieving the Alianza's quest 
for recognition of their autonomous land rights, it did establish their importance within the burgeoning movement for Chicano nationalism. ${ }^{45}$

The inability of Peace Corps community development training to accommodate and address forms of community action that challenged the established organization of power and resources, not only regionally but also in terms of the federally orchestrated appropriation of local Hispano resources on behalf of corporate capital, is not surprising. Future Peace Corps "agents of change" were after all agents of the federal government. What this inability makes exceedingly clear, however, is the acutely selective manner in which the framework or predicament of locality and place was deployed in Peace Corps training. An understanding of what such locality and place were supposed to accomplish varied considerably and somewhat predictably according to the administrative level of the Peace Corps bureaucracy. In fact, different administrative sectors of training embraced different methodological abstractions (of cultural difference, of underdevelopment, of experience), while these abstractions in turn offered those outside the Peace Corps a variety of forms of strategic negotiation and engagement.

\section{LESSONS ON THE VALUE OF D IFFERENCE}

When UNM's Peace Corps Training Center began in 1962 its programs insistently framed trainee field experience in local communities with extensive instruction on the theoretical principles of community development. Richard Poston, a well-known "expert" in the field and author of such books as Democracy Speaks Many Tongues, was hired to coordinate community development instruction. Training included lessons on the "dynamics of the community development process," "community as a social structure," and "patterns of behavior of peasant societies." Lectures covered the theoretically distinct "phases" of community development, which were to progress successively from "investigation" to "organization" to "implementation." Techniques were introduced for "the development of a viable citizens" organization that will stimulate local population toward responsible citizenship."46 Once in the field, trainees were expected to keep thorough daily logs of their activities and provide profiles of the families they met that described their "socio-economic characteristics," "migration history," "orientation and aspiration," and the family's "formal and informal relationships" to the larger community. At the conclusion of the field-training placement,

\footnotetext{
45 Peter Nabokov, Tijerina and the Courthouse Raid (Albuquerque: University of New Mexico Press, 1969); Richard Gardner, ;Grito!: Tijerina and the New Mexico Land Grant War of 1967 (Indianapolis: Bobbs-Merrill, 1970); Reies López Tijerina, They Called Me "King Tiger": My Struggle for the Land and Our Rights (Houston: Arte Público Press, 2000).

46 "Phase I \& II Lesson Plans," Community Development, Box 4, PC/CSWR.
} 
trainees would draft a summary of their work and a formal community evaluation. $^{47}$

Although trainees expressed mixed reactions to the classroom instruction, most viewed the field training as invaluable. A trainee placed in the northern town of Canjilón wrote, "the culture and way of life of these people was very different from anything I had previously encountered... I really got a taste of what it may be like to fit myself into a community in a foreign country." A trainee in Jemez Springs stated that "we were not in an extremely rural area, but even so, there was a degree of "culture shock.",48 In contrast to the academic training they received, trainees gravitated towards the field experience as "real," a tangible approximation of what they imagined their work in Latin America would be like. Trainees rarely questioned the intended contrast between themselves and the New Mexican villages into which they were inserted.

Outside evaluation of UNM's Peace Corps Training Center reiterated this emphasis on field experience as an encounter with cultural difference. In one such appraisal, the writer commented, "the classroom cannot replace the field in terms of presenting the actual difficulties of putting a community development program into effect." Indeed, the evaluator was "surprised and pleased to see that the frustrating, monotonous aspect of community development - the feeling of inadequacy that often confronts a Volunteer — could be duplicated." This duplication was possible because a purportedly universal set of characteristics were readily discernable. These qualities were easily transposable in the same manner that for many social scientists a "culture of poverty" supposedly transcended the particular circumstances of specific societies. Thus, the evaluator concluded, "The correlation of problems encountered in the neighborhoods of Las Vegas [New Mexico] to those veredas of Colombia was high, e.g., fatalism, pessimism, lack of faith in government, lack of faith in their neighbors." 49 While it was precisely this belief that situations and experiences volunteers would encounter abroad were capable of being replicated in poor and culturally unfamiliar contexts in the United States that underwrote the logic of Peace Corps field training to begin with, the necessity of enlisting cooperation of actual people for such projects complicated the simple transposition of universals.

Training materials for new Volunteers, written by Bill McKinstry, a Community Development Consultant in Pecos Valley, explained that field work was intended to accomplish two main goals: "(1) to give you a training ground to practice application of Community Development principles; (2) to provide

\footnotetext{
47 “Manual for PCV's Field Work," Training—Community Development—Field Training, Box 5, PC/CSWR.

48 "Field Experience - Colombia XIII," Evaluations, Oct. 1963; and "Group Leaders' ReportWeek of 'Field Utilization,' Colombia XIII," 19 Oct. 1963, Training — Community DevelopmentField Training, Box 4, PC/CSWR.

${ }^{49}$ Elliot V. Smith, "Peace Corps Training Center Evaluation, October 11, 1965," TrainingCommunity Development-Evaluation of Program, Box 7, PC/CSWR.
} 
a service to the community itself." Emphasizing the need to establish reciprocal benefits, he insisted, "Although the community is serving as a training ground and recognized as such by many people, we must do all we can to convince the people that we have something to offer them in return - a stimulus toward the development of a comprehensive community improvement program with a problem-solving mechanism (organization) which will perpetuate itself and reap benefits long after we are gone. In this sense, favors are being exchanged." 50

McKinstry endorsed the imperatives of the Peace Corps training curriculum - that trainees learn to develop a "comprehensive community improvement program"- but conceded that this goal would be impossible unless the people with whom such a program is organized consider it suitable to their particular needs. As outlined in a trainee handout, in order to avoid the community becoming "victim to a continual barrage of unrelated activities causing confusion and possible resentment," the activities of one cohort of trainees were to be coordinated with respect to those who had preceded them and those who would follow. ${ }^{51}$

Trainee desires were often at odds with the realities of field training. Perceptibly annoyed, John Arango, Community Development Coordinator at UNM's Peace Corps Training Center following Poston's departure, reported,

The trainees are constantly seeking something new in the experience, some accomplishment which no other group or trainee has before managed. In every group, one or more trainee reports begin: "I was glad to accept Ribera as my research site because (as opposed to many towns) it has been relatively untouched by previous trainees and I could do a realistic investigation." [...] One of the main problems facing the consultants is getting each trainee group to build on the work of previous groups. Because groups about to go into the field normally pay little attention to the reports from groups that have just returned, the consultants are now giving quizzes on the first day that the trainees are in the field ..."52

In this sense, trainee expectations corresponded with what the upper levels of the Peace Corps administration envisioned. For both, field training was supposed to provide an encounter with the radically unfamiliar, and, as such, to make "training as realistic as possible, to give volunteers a 'feel' of the situation they will face." $" 53$

50 Bill McKinstry, "Field Experience-Purpose," report reprinted in John Arango, "The Community Development Program of the University of New Mexico Peace Corps Training Center for Latin America" (Albuquerque, N.M.: June 1965), 134-45 (Report-Community Development Program 1965, Box 3, PC/CSWR).

51 Field Experience-Purpose, Training - Community Development-Training Plans in New Mexico 1965, Box 7, PC/CSWR.

52 John Arango, "The Community Development Program of the University of New Mexico Peace Corps Training Center for Latin America” (Albuquerque, N.M.: June 1965), 134 (ReportCommunity Development Program 1965, Box 3, PC/CSWR).

53 Peace Corps, Second Annual Report, 36. 
Arango, by contrast, distinguished between two approaches to training operative in the Peace Corps preparation of its volunteers. With the first approach, "acculturation training[,] . . . the goal is to place the trainee in a situation much different from those he is accustomed to, in order to test his ability to adapt to different cultures." The objective of the second more strictly vocational method, "community development field training[,] ... is to give the trainees practical experience in a community development program." 54 The tension and slippage between these two distinct field-training paradigms is significant as an index of the political imaginary of place and the tactical maneuvering for material resources and political legitimacy.

Responding to criticism of UNM's field training program expressed in a memo from the director of the Peace Corps in Colombia, Arango detailed his perspective on why the UNM program was geared towards the community development field training approach. His rejoinder reveals differences that existed as well between the official training rhetoric of UNM, which often promoted the ostensible realism of its cultural simulation instruction, and the outlook of training staff with ongoing relationships with the communities where training was staged. Arango went so far as to contrast UNM training to other Peace Corps field training, asserting, "most Volunteers readily adapt to strange living conditions, but have difficulty applying the community development method. The situations we choose for field training are selected not for their similarities with Latin America . . . , but because they present close parallels to the community development situation in Latin America." Instead of emphasizing the adjustment of trainees to "a new culture," Arango stressed the techniques of community development. Traveling to Ecuador, Peru, and Bolivia, he observed, "it is significant that groups which were trained in community development field situations, as opposed to acculturation situations, produced more Volunteers who were community organizers, or organization oriented community workers." 55 As the UNM Peace Corps Training Center Community Development Coordinator, Arango's perspective shaped the training curriculum. His agenda, however, also cut sharply against the grain of field training descriptions provided by former PCTC director Marshall Nason and UNM president Tom Popejoy, as well as the higher echelons of the Peace Corps administration responsible for training.

After a tour of South American Peace Corps projects in early 1965, Arango reported his observations to Jules Pagano, Acting Director of Peace Corps University Relations and Training. Frustrated with the Peace Corps training practice of treating host countries as culturally homogeneous places, Arango protested, "I personally believe that the training of Volunteers for a whole

\footnotetext{
54 Arango, "The Community Development Program," 51.

55 John Arango, memo to David T. Benedetti, Director of the UNM Peace Corps Training Center, 14 Apr. 1965, 5-6, Correspondence-General 1965, Box 3, PC/CSWR.
} 
country at a time is wasteful, and that for community development training at least, the training should be structured around regional assignments." ${ }^{\text {" }} \mathrm{He}$ noted, for instance, how inappropriate it was to teach all volunteers assigned to Peru a single dialect of Quechua. He outlined significant differences in the dynamics of the communities he visited in Huancayo, Cuzco, and Puno, and recommended how instruction might be variously tailored to local needs.

In Education in the Peace Corps: Evolving Concepts of Volunteer Training, an official summation of Peace Corps training written by Jules Pagano several months after Arango's letter to him, the indiscriminate terms of "cultural immersion" remained at the forefront of the agency's training agenda. Pagano emphasized the benefits of cultural immersion and the transposability of the foreign: "Trainees must be prepared to operate in a culture which is not only foreign, but also non-Western - a great leap in thought and mores. And their subjects will speak a different language-both literally and figuratively... The fundamental principle of Peace Corps training ... is the notion of total cultural immersion; the ultimate effect is a 'liberally educated' Volunteer." 57

In his description of everyday field training activities, the predominance of "total cultural immersion" appears more ambiguous but is still recuperated:

The State of New Mexico has been the scene of much of our rural community action field work.... One group recently spent two weeks scattered in the outer reaches of New Mexico, going through a field exercise surveying communities. The trainees become deeply involved in the life of their respective towns, and they were enraptured by the experience. Their typically American composure was shaken. What they saw and the conditions found gave them a somewhat different slant on the "great society." One trainee summed up his worry about his ability to be useful in Chile. "If I can transport my feelings of humility with me overseas, maybe I will have some degree of success." 58

Vocational training is subsumed under an explicit imperative to engage the emotional and psychological dimensions of trainees. Despite running counter to the guidelines provided by McKinstry and the vocational emphasis of Arango, the overarching model of field training prioritized the inner transformation of individual trainees triggered by an unsettling encounter with the unfamiliar.

Local support for Peace Corps training in north central New Mexico provides a sense of the calculated invocation of the foreign. Such support often simply reproduced the language and logic of Peace Corps training. For instance, an editorial in Santa Fe's The New Mexican, expressing concern that Peace Corps training activities in the Taos area were going to be closed down, replicated almost exactly the terms of the UNM Peace Corps training proposal. The

\footnotetext{
56 John Arango, letter to Jules Pagano, 8 Feb. 1965, Correspondence-General 1965, Box 3, PC/CSWR.

57 Jules Pagano, Education in the Peace Corps: Evolving Concepts of Volunteer Training (Boston: Boston University Center for the Study of Liberal Education for Adults, 1965), vii.

58 Pagano, Education in the Peace Corps, 34.
} 
author asserted that "the nearest these students will ever come to their foreign assignments, without actually leaving the United States, is in the economically depressed rural areas of the Southwest where even the language is similar to that spoken in the areas in which they will later serve." The author of the editorial insisted that the Peace Corps training had provided invaluable services in northern New Mexico that facilitated ongoing development. Trainees, the writer argued, "demonstrated the kind of outside help many in the rural villages want - not a person who tells the local folks what to do, but persons who roll up their sleeves and show them things can be done."59

Local criticism of the field training, by contrast, often asserted the already operative indigenous forms of community organization. This was expressed by noting ways in which the training was disruptive rather than constructive. Residents criticized the field training by arguing that local forms of community organization were disrupted or undermined by the field training initiatives. For instance, a community organizer from the town of Llano complained to the Training Center's Director, "It has always been my understanding that what the trainees are doing is learning how to organize communities not to create new groups and frictions among them." 60

In one local newspaper, the Las Vegas Daily Optic, whose front page regularly featured republished international and national newswire items alongside coverage of high school debate team activities and the minutiae of municipal budget meetings, Peace Corps field training appears as just another public works project. A characteristic story read in typical deadpan prose: "The Peace Corps will visit homes, talk to people, investigate problems and seek solutions with existing organizations." ${ }^{\text {" I }}$ Ironically, it was not local controversy that precipitated the end of UNM's program. Bureaucratic conflicts with the Washington Peace Corps office lead to the cancellation of the training contract in $1967 .{ }^{62}$ In all, UNM trained over 1,800 volunteers for service in eight Latin American countries.

By the time the UNM program had reached its demise, the Peace Corps central office was looking to more clearly systemize its training efforts.

59 “No Changes, Please," The New Mexican, 6 Dec. 1963: n.p.

60 Letter, Crisóforo Martínez to Marshall Nason, Director, UNM Peace Corps Training, 28 Mar. 1964, El Llano, N.M., Training-Community Development, Box 7, PC/CSWR.

61 The quotation is from "Peace Corps Trainees Enroute to Villanueva...," Daily Optic, 22 Apr. 1964: 1. Also see "New Peace Corps Members Arrive," Daily Optic, 8 May 1964: 1; "Peace Corps Work Continues," Daily Optic, 8 May 1964: 1; "Villanueva Area Development Group Elects," Daily Optic, 16 June 1964: 1.

62 “U.S. Peace Corps Training Center to Close Jan. 21," Albuquerque Journal, 5 Jan. 1967: n.p. (Newspaper articles-1967, Box 3, PC/CSWR). Lack of University enthusiasm was probably a contributing factor as well. UNM President Tom Popejoy wrote Peace Corps Training Center Director David Benedetti, "it seems to me that this is an appropriate time for us to give more attention to instructional and research programs which relate to South America" (16 Jan. 1967, Correspondence-General-1967, Box 3, PC/CSWR). 
In 1968, this process was entrusted to the Center for Research and Education in Estes Park, Colorado. Two years later the Center published a massive fourvolume study and manual entitled Guidelines for Peace Corps Cross-Cultural Training. The authors concluded, "one thing most if not all Peace Corps Volunteers have in common is that they have to enter, live, and work in a culture quite different from their own." Thus, of foremost concern was acculturation that allowed for trainee empathy while maintaining their exemplary role as Americans: "Trainees need to develop an understanding and tolerance of differences between values, beliefs, assumptions, needs, attitudes, and behavior, particularly of individuals from different social and cultural backgrounds, and an awareness of the conflicts and problems that can arise from these differences. They need to learn to adapt their own values, needs, etc. to those of the culture within which they wish to work, without losing their identity as Americans." 63

What the guidelines make exhaustively clear is how the emerging educational philosophy of experiential learning easily integrated vocational training into the acculturation model and was capable of dissolving the methodological distinction Arango underscored. If in Arango's own comparison between "acculturation" and "community development field training" the distinction often appeared tenuous, his emphasis on the latter did ground training through a more explicit interaction with the actual people with whom trainees were working.

\section{AT THE LIMIT OF COLONIAL DIFFERENCE}

If Peace Corps field training presumed a certain coherent and universal form of difference, it imagined an equally homogeneous and generic Peace Corps volunteer. The calculated shock of difference supplied by field placement in local communities was conceivable only to the degree that such communities were perceived as different and unfamiliar. To be sure, the lens of universality engendered recognizable tropes, such as the simplicity and authenticity of preindustrial life. That the "cross-cultural" experience could be rendered within an anticipated narrative, however, did not diminish the expectation that it was to be for the trainee a marked encounter with the different and unfamiliar.

The presumption of a single volunteer type posed difficulties for an assertively liberal agency rhetorically committed to inclusivity during the high tide of the civil rights movement. Thus, throughout the 1960s the Peace Corps sought to counter the image of Peace Corps volunteers as white and economically privileged. The agency widely promoted its efforts to recruit African Americans and native Spanish speakers, but often found its liberal "color-blind"

63 Albert R. Wight and Mary Anne Hammons, Guidelines for Peace Corps Cross-Cultural Training, 4 vols. (Estes Park, Colo.: Center for Research and Education, and Washington, D.C.: Peace Corps Office of Training Support, 1970), ix, x. 
philosophy at odds with actually existing structural inequalities and unable to accommodate the realities of racial prejudice. ${ }^{64}$ The total number of African American volunteers, estimated at a meager 5 percent between 1961 and 1965 , dropped to less than two percent by $1969 .{ }^{65}$ The agency's few explicitly class-based recruitment initiatives fared similarly. A "blue collar" envoy of mechanics, machinists, and welders was organized by the agency and dispatched in 1965 to Chile, but was not followed by any comparable endeavor. ${ }^{66}$ For many, two years of volunteer service without other guarantees of economic support was an impossible luxury. The Peace Corps' "vow of poverty" was itself an indulgence incongruous with the daily lives of those already struggling with racially over-determined conditions of poverty.

In late 1966 representatives of the Oklahomans for Indian Opportunity (OIO), an Office of Economic Opportunity-funded group lead by Comanche activist LaDonna Harris, approached the Peace Corps with the idea of developing a program to recruit and train American Indians to serve as Peace Corps volunteers in Latin America. The initial proposal promoted the project as "a way of interesting American Indian youngsters in the Peace Corps and many American Indian Peace Corps volunteers returning to be of service to the Indian community in this nation. Part of the purpose of Peace Pipe is to develop American Indian leadership. Peace Corps service is an excellent vehicle for reaching this end." ${ }^{\prime 67}$ The OIO and the Peace Corps devised a fiveweek pre-training program called Project Peace Pipe and publicized the endeavor with funding from the Bureau of Indian Affairs. ${ }^{68}$

In an essay on the project in the Journal of American Indian Education, Harris and University of Oklahoma social work professor Leon Ginsberg underscored that "reaching persons who are closely identified with their groups and who are also socio-economically deprived probably requires

64 "Peace Corps: Negroes Play Vital Role in U.S. Quest for Friends Abroad," Ebony 17 (Nov. 1961): 38-40; "Peace Corps Training at Howard: Negro University Prepares Interracial Group for U.S. Good-Will Missions Abroad," Ebony 18 (Nov. 1962): 69-77; Juanita Thurston, "Valuable Job of Volunteer," Christian Science Monitor (16 June 1971): 12; "Minority Activity in the Peace Corps," Congressional Record 117, 18 (6 July 1971), 23541-42; Jonathan Zimmerman, "Beyond Double Consciousness: Black Peace Corps Volunteers in Africa, 1961-1971," Journal of American History 82, 3 (Dec. 1995): 999-1028; Julius A. Amin, "The Peace Corps and the Struggle for African American Equality,” Journal of Black Studies 29, 6 (July 1999): 809-26.

65 Brent Ashabranner, A Moment in History: The First Ten Years of the Peace Corps (Garden City: Doubleday \& Co., 1971), 259.

66 Memo, Sargent Shriver to the President, 27 July 1965, "Weekly Report of Peace Corps Activities," Peace Corps 1965, Box 129, Confidential Files, Agency Reports, Lyndon B. Johnson Library, Austin, Texas.

67 Leon Ginsburg, "Project Peace Pipe" (Report presented at the Oklahomans for Indian Opportunity board meeting, 8 July 1967), 3; Fred R. Harris Collection, Box 284, Folder 16; Carl Albert Congressional Research and Studies Center, Congressional Archives, University of Oklahoma, Norman.

68 LaDonna Harris, LaDonna Harris: A Comanche Life, H. Henrietta Stockel, ed. (Lincoln: University of Nebraska Press, 2000), 59-64, 80-82. 
special recruitment efforts ... Normal Peace Corps advertising and recruiting efforts, which focus on major college campuses, are not enough."69 Moreover, in addition to recruitment, Harris and Ginsberg concluded that pre-training would facilitate volunteer retention. While for young middle-class whites there appeared little doubt as to whether they might have something to contribute to impoverished people abroad, Project Peace Pipe focused on dispelling the historically ingrained devaluation and self-doubts of Indian trainees. Concerned with redressing the psychological effects of internal colonization, the project emphasized the racialized and economic inequalities within the United States rather than impending "culture shock" abroad. Thus, Harris and Ginsberg argued, "While the rigors of overseas life could pose adjustment problems to middle and upper socio-economic class volunteers, they would be less frightening, it seemed, to reservation-reared or rural Indian young persons. It was the fellow trainee group that could cause the most serious difficultiesperhaps a failure in training-for the American Indian."70 Cause for failure in training potentially had more to do with disparities between relatively privileged white trainees and American Indian recruits. The OIO, inverting the Peace Corps "cross-cultural" training model, sought to utilize training as a means to address internal structures of dominance rather than prepare volunteers for encountering those structures abroad.

If the Peace Corps were concerned with the recruitment of people of color largely for the sake of appearance, the OIO project seized upon this facile image as a concrete means of intervening in dominant institutional relations of power. This intervention was aimed both at transforming the local individualized consequences of internal colonialism and at appropriating the representational power mobilized on behalf of the Peace Corps role in U.S. diplomacy.

Scholars such as historian Fritz Fischer have pointed to Project Peace Pipe as a failed Peace Corps endeavor, and an example of the ethnocentric and exceptionalist Peace Corps mission to "make them like us." "71 This interpretation misunderstands the genesis of the project. Initiated by LaDonna Harris and the OIO, Project Peace Pipe used the conventions and prestige of the Peace Corps idea as a counterforce to the social and institutional constructions of "domestic dependency." That the Peace Corps retreated from the project after only three years and two cohorts of trainees was indeed evidence of the agency's racial and class-based presuppositions. ${ }^{72}$ Only two Indian recruits

${ }^{69}$ Mrs. Fred R. Harris [LaDonna Harris] and Leon H. Ginsberg, "Project Peace Pipe: Indian Youth Pre-Trained for Peace Corps Duty," Journal of American Indian Education 7, 2 (Jan. 1968): 26.

70 Harris and Ginsberg, "Project Peace Pipe": 23.

71 Fritz Fischer, Making Them Like Us: Peace Corps Volunteers in the 1960s (Washington, D.C.: Smithsonian Institution Press, 1998), 102-3.

${ }^{72}$ On this point, also see Ashabranner, A Moment in History, 268-70; and Jack Anderson, "Peace Corps Indian Project Fails," Washington Post, 4 Nov. 1970: B19. 
completed training and overseas assignments; one went on to work for Americans for Indian Opportunity (an outgrowth of OIO) and the other later became vice president of the Jicarilla Apache. ${ }^{73}$ However, to focus only on this failure is to miss the significance of the fact that it was an Indian-initiated project. Fischer reads the project literally, as yet another chauvinist gesture towards assimilation, but the attempt to place on the world stage American Indian youth working with communities in the so-called Third World provided an opportunity to unsettle relations of internal colonialism and to underscore historical interdependencies of European and U.S. colonialism. Such a possibility gained in consequence precisely because of the kind of constructions of difference and universality deployed in Peace Corps field training. Indeed, the colonial difference of the American Indian trainees, and the still operative conditions of U.S. colonialism underscored by their participation, proved to be fundamentally incompatible with U.S. Cold War liberal universality and the versions of foreignness that it authorized. To recognize colonialism as constitutive of the United States would render the country perilously foreign to itself, and destabilize the moral and cultural claims that sustained the "internal border" of U.S. national unity. The radical conditionality of this unity, in the context of U.S. Cold War grand strategy, embraced an ethics of liberal pluralism only in a manner that still constituted a single, unitary subject of the ostensibly exceptional nation. ${ }^{74}$

PROVISIONAL SUBJECTS AND "REAL UNIVERSALITY"

Perhaps most striking about the Peace Corps field training initiatives is the manner in which they drew attention to the very conditions that the Peace Corps sought to disavow. How, after all, could the United States claim the expertise to solve the problems of poverty abroad if it was unable to do so within its own borders? As such, the explicit parallel between impoverished, culturally distinct domestic areas and poor nations overseas registered two competing versions of U.S. globalism. First, the State Department promoted the United States as the fulfillment of human history, a paragon also devoted to assisting "underdeveloped" parts of the world in realizing their aspirations to this ideal. The U.S. example seemingly transcended the particularities of culture and place, but qualified universal inclusion with a hierarchically differentiated teleology emphasizing the developmental distance between the U.S. and other nation-states. Second, U.S. competence to intervene in matters of underdevelopment globally could be claimed through this ongoing practice

\footnotetext{
73 Interview with LaDonna Harris, 6 June 2006, Albuquerque, New Mexico.

74 For discussions of the "internal border," see Étienne Balibar, "Fichte and the Internal Border: On Addresses to the German Nation," in Masses, Classes, Ideas (New York: Routledge, 1994); and Marc Redfield, "Imagi-Nation: The Imagined Community and the Aesthetics of Mourning" in, Jonathan Culler and Pheng Cheah, eds., Grounds of Comparison: Around the Work of Benedict Anderson (New York: Routledge, 2003), 75-105.
} 
of domestic intervention. Thus, the affluent society's knowledge of and experience with the "problems of cultural adaptation in the process of economic development" were exactly the qualifications required for world leadership. Against the conceits of both affirmative U.S. globalisms was the fact that territories or peoples within the United States and the world at large shared a history of colonization and dispossession. This suggested lines of conflict decisively at odds with the interests of U.S. Cold War policy.

While Truman firmly cast underdevelopment elsewhere, the examples discussed in this essay suggest ways in which the global logic of development proved less tidy and manageable than U.S. policymakers had anticipated. Rather than simply stigmatizing entire nations and naturalizing an apparently irrepressible process of economic growth, underdevelopment also introduced a new space of strategic negotiation. Nevertheless, these negotiations ran aground whenever the conditions of U.S. colonialism became too visible a point of reference.

The particularities evident in both the NCAI campaign and the local contexts of Peace Corps training challenged the abstraction of universality, specifying explicit histories of exclusion while still pursuing a strategic inclusivity. In each case, the inscription of global paradigms of "poverty" and cultural difference, rather than achieving the seamless imposition of social meaning, functioned as arenas for action. In none of these instances is the significance of "poverty" and cultural difference exhaustively universalized, because they are always remade in their concretely manifest forms. Philosopher Étienne Balibar has described among three salient forms of universality a conception of "real universality," which is the historical moment when "humankind" is experienced as an actual condition of global interconnectivity rather than as an ideal or utopian future. Balibar insists, however, "far from representing a situation of mutual recognition, it actually coincides with a generalized pattern of conflicts, hierarchies, and exclusions." 75 Under conditions of "real universality," identity is increasingly strategic because of the inequities exasperated by globalized interdependency. In other words, inequities - often themselves the residue of historical dispossessions wrought by preceding globalizations such as colonialism - animate identity as strategy. It is in this sense that underdevelopment was an arena for action and intermediation rather than as a dictated and fixed term of identity.

The observations of political scientist Uday Singh Mehta on the imperial constitution of liberal thought are particularly useful here. Taking shape

75 Étienne Balibar, Politics and the Other Scene (London: Verso, 2002), 154. Balibar contrasts "real universality" with "fictive universality" and "ideal universality." Fictive universality has to do with the domain of institutions and representations. Ideal universality is intended to suggest "the fact that universality also exists as an ideal, in the form of absolute or infinite claims which are symbolically raised against the limits of any institution" (163-64). 
in the British colonial context, liberal universalism was less an unfulfilled ideal toward which its progenitors aspired than a particular logic of colonial administrative practices. Mehta focuses on the exclusionary strategies embedded in liberal universalism, and, rather than suggesting that such strategies incite contradiction, points to the circumstances of colonial India within which liberal philosophers such as John Stuart Mill and James Mill conceived of the liberal project. ${ }^{76}$

Foregrounding this imperial context, Mehta poses the important question: "What was the response of liberal theorists as they cast their gaze on an unfamiliar world?" According to him, these theorists perceived unfamiliar forms of experience and life as provisional. Particularities foreign to their own understanding and worldview were merely circumstantial details that obscured the essential truth of their own perspective. Their response to such provisionality, Mehta argues, was to insist that they were obligated to intervene on behalf of that which was "incomplete, static, backward, or otherwise regnant, and guide it to a higher plateau of stability, freedom, and purposefulness." Indeed, their claim was that such intervention was not pursued in self-interest but rather for the greater good and essential truth that liberal imperialists had the rational capacity to recognize. At the core of liberal justification for empire, and of the liberal social mission more broadly, was the judgment that the provisionality of other peoples' experience required normative remediation. Mehta puts this succinctly, stating, "The will to power that liberals do express for the empire is always as a beneficent compensation for someone else's powerlessness relative to a more elevated order."77 The historical negotiations examined in this essay, I suggest, were necessarily animated by this still preponderant liberal enterprise.

Significant historical differences separate the Truman era from the Kennedy and Johnson administrations, especially with regard to how domestic policy was cast in relation to Cold War grand strategy, but discursive continuities did persist. In 1964, President Johnson appointed Peace Corps Director Sargent Shriver to head the recently legislated Office of Economic Opportunity and lead the domestic "War on Poverty." For two years, Shriver served as director for both the OEO and the Peace Corps. His efforts to subsume both agencies into a single mission are immensely telling. Shriver went so far as to insist, "[T] he best evidence I have that both of the agencies I'm running are successful [is when a] guy who agitated for the poor in Peru for two years took that training and used it, and is now working for OEO to get the poor to demand that they be allowed to participate in city council meetings."78 Likewise, seeking to

76 Uday Singh Mehta, Liberalism and Empire: A Study in Nineteenth-Century British Liberal Thought (Chicago: University of Chicago Press, 1999), 46.

77 Mehta, Liberalism and Empire, 191.

78 As quoted in Cobbs Hoffman, All You Need Is Love, 197. 
recruit the support of the American Society of Newspaper Editors for the War on Poverty in 1964, Shriver insisted that the programs were in tune with U.S. free market ideologies and joked, "The Communists have been calling me an agent of Wall Street imperialism ever since the Peace Corps got started. Not bad for a Democrat!! But for the first time they may be right." In this same address Shriver noted, "Peace Corps Volunteers who have completed their service abroad, were queried about the poverty program. Eighty-two percent of them said they were interested in joining. From this source alone we can anticipate 2,847 dedicated workers next autumn."79 Because they suffered from the same ostensible cultural deficiencies as the "underdeveloped" hosts abroad, impoverished populations within the United States could benefit from the Peace Corps in the form of War on Poverty community action agents.

The construct of culture shock, however, also proved to be malleable. In 1970, the Navajo Nation, with the support of several prominent social scientists, challenged a negative evaluation of its Office of Economic Opportunityfunded Rough Rock Demonstration School by claiming that the OEO's evaluators suffered from culture shock and as such were incapable of objectively appraising the project. The school's advisory board contended, "Our claim is that the Rough Rock evaluators, unknown to themselves, were overwhelmed by the impact of the new school culture and that their report was written under severe culture shock due to unfamiliarity with Navajo culture." 80 Among other points, the OEO report criticized the school for not fully implementing the War on Poverty mandate for community control. The board thus countered that the evaluators were in fact unable to recognize community control, blinded as they were by cultural preconceptions and disoriented by the unfamiliar context.

The strategic use of culture shock by the Navajo school board cut against the grain of liberal universality because it disallowed the assimilability of difference. The foreign, as I have discussed in this essay, was vital to the mechanics of liberal reform because it served as a representation of the absolute other as essentially the same; that is, as a provisional subject awaiting transformation into its immanent sameness. By charging that OEO evaluators were debilitated by culture shock, Navajo leaders both insisted upon the situated particularity of difference - that a group of white experts might not have the capacity to recognize what they observed - and called attention to this liberal presumption of sameness.

The limit of liberal universality was the particularity of its own historical and material conditions of possibility. Examining the foundational role of the foreign

\footnotetext{
79 "Address by Sargent Shriver before the American Society of Newspaper Editors, Washington, D.C., 18 Apr. 1964," Aides Files-Richard N. Goodwin, Box 24; Poverty Speeches; Lyndon B. Johnson Library, Austin, Texas.

80 “The Werner Report: Board Dissents with Report," Navajo Times, 15 Jan. 1970: 19.
} 
for liberal reform, and its specific dynamics within the mid-twentieth-century discourse of underdevelopment, reveals the ways in which U.S. colonialism served as both an impossible referent and a structuring absence in the U.S. Cold War construction of the "free world." 